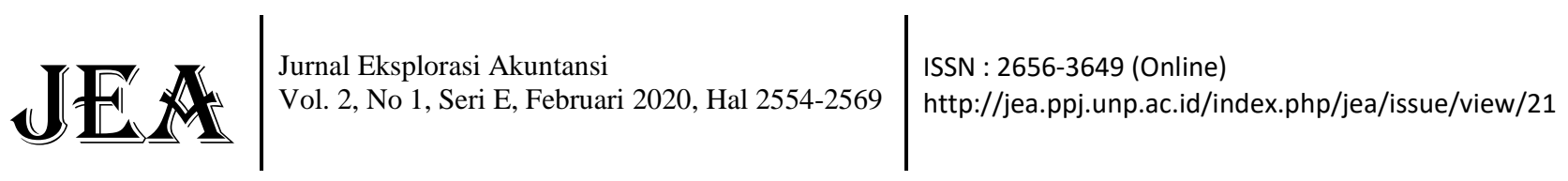

\section{PENGARUH DEWAN KOMISARIS, KOMITE AUDIT, DAN DEWAN PENGAWAS SYARIAH TERHADAP KINERJA PERBANKAN SYARIAH}

\section{(Studi Empiris Pada Perbankan Syariah Tahun 2014-2018)}

\author{
Jumaini Azizah', Erinos NR ${ }^{2}$ \\ ${ }^{1}$ Alumni Jurusan Akuntansi Fakultas Ekonomi, Universitas Negeri Padang \\ ${ }^{2}$ Jurusan Akuntansi Fakultas Ekonomi, Universitas Negeri Padang \\ *Korespondensi: jumaini.azizah@gmail.com
}

\begin{abstract}
This study aims to determine and analyze the influence of the Board of Commissioners, the Audit Committee and the Sharia Supervisory Board on the Performance of Sharia commercial banks Empirical studies on Sharia commercial banks in 2014-2018 both simultaneously and in part. The data analysis method used is panel data regression analysis. Using a purposive sampling method to get a sample of 10 Islamic banks from 12 Islamic banks. Based on the results of the study note that the board of commissioners, audit committees, sharia supervisory boards simultaneously affect the performance of Islamic banks. But partially, the board of commissioners, audit committee, sharia supervisory board did not affect the performance of Islamic Banks in Islamic Banking in 2014-2018.
\end{abstract}

Keywords: Audit Committee; Board of Commissioners; Sharia Supervisory Board

How to cite (APA $6^{\text {th }}$ style):

Azizah, J. \& Erinos, NR. (2019). Pengaruh Dewan Komisaris, Komite Audit Dan Dewan Komisaris Syariah Terhadap Kinerja Perbankan Syariah (Studi Empiris pada Perbankan Syariah Tahun 2014-2018). Jurnal Eksplorasi Akuntansi, 2(1), Seri E, 2554-2569.

\section{PENDAHULUAN}

Kinerja diartikan dengan bentuk pencapaian atau cerminan dari suatu pekerjaan yang dilakukan (Stolovitch and Keeps, 1992). Kinerja perusahaan dikatakan baik tampak dengan tercapainya tujuan awal yang telah direncanakan (Donelly, Gibson and Ivancevich, 1994). Febriani (2003) berpendapat, pada setiap perusahaan diseluruh negara menfokuskan hasil kinerja yang dicapai menjadi tolak ukur dari sukses atau tidaknya perusahaan tersebut. Menjadi tolak ukur bermakna bahwa kinerja adalah hal yang sangat penting, karena pada hasil kinerja kita dapat menilai bagaimana pengelolaan dan pengalokasian dari sumber daya pada perusahaan. Perusahaan jasa pasti dinilai dengan melihat hasil kinerja perusahaan, begitupun perusahaan jasa seperti bank dan juga termasuk bank syariah.

Dewasa ini, perusahaan perbankan syariah terus menunjukan peforma yang terus maju dan bertumbuh dengan pesat, hasil ini terlihat tidak hanya di Indonesia tetapi juga di dunia internasonal. Perkembangan perbankan syariah kini telah banyak diterima seiring dengan 
pemikiran masyarakat yang terbuka dan kemajuan zaman, yang dulunya konsep ini hanya sebatas diskusi teoritis saja. Pada zaman sekarang perbankan syariah sudah menjadi perbincangan dunia, tidak hanya pada negara dengan penduduk mayoritas beragama islam namun juga sudah merembes kenegara yang minoritas beragama islam. Melihat perkembangan pesat yang terjadi di Indonesia ini membuat penilaian dan pengawasan pada lembaga perbankan syariah menjadi hal yang sangat penting untuk kita teliti.

Kemajuan perbankan syariah di Indonesia terus memperlihatkan sisi positif serta membawa harapan yang positif. Di Indonesia, bank syariah sendiri diperkirakan akan mengalami perkembangan pesat dan terus tumbuh. Harapan lain juga muncul seiring perkembangan industri lembaga keuangan syariah di Indonesia, yaitu diharapkan bisa memberi kekuatan demi tercapaiknya kestabilan pada sistem keuangan nasional dimasa yang akan datang. Bank Indonesia pada tahun 2006 telah melakukan penelitian tentang pendapat masyarakat terhadap bank syariah, yang hasilnya menunjukan bahwa minat masyarakat terhadap bank syariah sangat tinggi. Sisi lain hasil penelitian ini juga menunjukan adanya keluhan atas kualitas pelayanan, termasuk keterjanglkauan jaringan yang rendah oleh sebagian besar responden (Wibowo, 2009:1).

Pesatnya perkembangan yang terjadi pada lembaga keuangan syariah, membuat pihak perbankan syariah harus memiliki pengawasan terhadap semua unit usaha, kegiatan yang dilakukan dan bagaimana proses jalannya semua akktifitas pada perbankan syariah. Setiap Bank Syariah diharuskan mempunyai lembaga atau orang-orang yang memiliki tugas untuk melakukan pengawasan terhadap seluruh aktifitas pada bank syariah. Dewan komisaris, komite audit serta dewan pengawas syariah akan diberikan kewenangan untuk mengawasi dan juga untuk memantau patuh atau tidaknya karyawan Bank Syariah terhadap kebijakan, prosedur, dan aturan yang telah ditetapkan oleh Bank Syariah tersebut. Dewan komisaris, komite audit dan dewan pengawas syariah yang terdapat disetiap Bank Syariah akan memastikan seluruh proses atau kegiatan perbankan yang dilakukan memiliki pegawasan agar kegiatan dlakukan sesuai dengan standar yang berlaku.

Pengawasan aktivitas-aktivitas pada bank syariah dilakukan oleh Dewan komisaris. Dewan komisaris adalah organ perseroan yang tugasnya yaitu mengawasi seatu perusahaan atau lembaga baik secara umum ataupun khusus sesuai dengan anggaran dasar serta memberi nasihat kepada direksi, (Rustam 2013:400). Decow, et al. (1996) dan Beasly (1996) dalam Sam"an (2008) memperlihatkan adanya hubungan yang signifikan antara jumlah dewan komisaris dengan kinerja. Mereka berpendapat bahwa jumlah dan independensi dewan komisaris dapat mempengaruh kemampuan mereka dalam memantau proses pelaporan keuangan. Pelaporan keuangan berhubungan erat dengan kinerja dari suatu perusahaan. Nama baik, keinginan dan iktikad baik saja tidak cukup untuk menciptakan dewan komisaris berstandar dunia, peran aktif dewan komisaris diperlikan untuk mendapatkan struktur, sistem dan proses yang memadai, Dewan komisaris juga harus independen dan konstruktif (Alijoyo.A, 5: 2004).

Pengawasan aktivitas perbankan syariah juga dilakukan oleh Komite Audit. Komite audit adalah orang yang ditunjuk untuk mengerjakan perkerjaan khusus atau untuk melakukan tugastugas tertentu atau sejumlah anggota Dewan Komisaris perusahaan klien yang memiliki tanggungjawab untuk membantu auditor dalam mempertahankan independensi dari manajemen, (Tugiman, 1995). Di Indonesia komite audit memang belum lama dipulbikasikan, tetapi komite audit sudah sejak lama didirikan di negara maju seperti Amerika Serikat, Kanada, dan Inggris. Tahun 1967 American Institude of Certified Public Accountant (AICPA) mengeluarkan pernyataan yang berisi rekomendasi agar setiap perusahaan yang sudah terdaftar di bursa efek 
atau sahamnya sudah diperjual belikandi bursa saham agar membuat suatu komite yang berisi orang-orang yang bukan merupakan pejabat perusahaan, yang memiliki kewenangan menunjuk auditor independen dan secara continue mengikuti kegiatan yang dilaksanakan oleh auditor tersebut, (Marini, 2001:207). Ni Nyoman, Ramdiani dan I Ketut Yadnyana (2013), menemukan adanya pengaruh signifikan antara ukuran komite audit terhadap kinerja pada perbankan syariah yang diukur menggunakan return on asset (ROA).

Dewan Pengawas Syariah juga tidak lepas dari tanggung jawabnya untuk melakukan pengawasan terhadap aktivitas perbankan syariah serta dewan yang harus ada pada perbankkan syariah. Rustam (2013:414) menyatakan bahwa, "Dewan Pengawas Syariah (DPS) ialah dewan yang memiliki tugas penting yaitu memberikan nasehat ataupun saran kepada direksi, tidak hanya itu DPS juga bertugas melakukan pengawasan pada setiap aktifitas bank agar tidak melenceng dari prinsip-prinsip syariah yang ada. DPS memiliki fungsi untuk melakukan pengawasan dan memastikan setiap proses dan aktifitas bank syariah agar sesuai dan tidak menyimpang dari ketentuan syariat islam yang berlaku. Pengawasan ini bukan tanpa tujuan, hal ini disebabkan akad atau transaksi dari bank syariah yang berlaku tidak sama dengan sistem yang ada pada bank konvensional. Untuk menjamin bahwa bank syariah yang diawasi oleh DPS tersebut sesuai aturan atau tidaknya, DPS harus membuat pelaporan berupa pernyataan secara berkala. Pernyataan DPS ini disampaikan dalam buku laporan tahunan (annual raport) bank yang bersangkuatan.

Selain pengawasan. DPS juga memiliki tugas lain yaitu melakukan penelitian serta membuat saran untuk produk baru dari bank syariah yang sedang diawasi. DPS juga memilki peran yaitu sebagai penelaah atas produk baru yang telah diteliti dan difatwakan oleh dewan syariah nasional (Antonio, 2001:25). Ni Nyoman, Ramdiani dan I Ketut Yadnyana (2013), menemukan adanya pengaruh yang signifikan antara dewan pengawas syariah terhadap kinerja pada perbankan syariah yang diukur menggunakan return on asset (ROA). Berdasarkan latar belakang diatasdan mengacu pada penelitian-penelitian sebelumnya, peneliti tertarik untuk meneliti tentang "Pengaruh dewan komisaris, komite audit, dan dewan pengawas syariah terhadap Kinerja Perbankan Syariah di Indonesia Periode 2014 - 2018”.

\section{REVIEW LITERATUR DAN HIPOTESIS}

\section{Teori Keagenan}

Agency theory dikatakan juga sebagai hubungan yang terikat kontrak antara principal dan agent (Anthony dan Govindarajan, 1995). Principal memberi tugas kepada agent termasuk pemberian wewenang, pengambilan keputusan yang tentu saja demi kepentingan principal. Agency theory adalah teori dengan pemisahan tugas dan wewenang antara pemilik dan pengelola perusahaan. Adanya pemisahan tugas ini membuat timbulnya konflik kepentingan yang saling bertentangan antara pemilik dan pengelola, (Destika, 2011;12).

Variabel Dewan Pengawas Syariah, Komite Audit dan Dewan Komisaris didalam penelitian ini berlandaskan kepada agency theory (teori agensi). Teori ini menjelaskan terkait hubungan antara pemilik dan agen. Jensen and Meckling (1976) menjelaskan bahwa adanya kontrak antara penyewa dan yang dipekerjakan, dimana penyewa akan memberikan kuasa penuh atas pengambilajn keputusan kepada agen.

Kinerja agen akan dilihat dan dinilai oleh prinsipal sesuai dengan bagaimana agen dapat meningkatkan laba yang nantinya akan memperbesar pendapatan deviden untuk prinsipal. Semakin besar tingkat laba atau deviden yang didapat prinsipal maka secara otomatis agen akan dinilai sukses dan bekerja dengan baik, oleh karena itu agen juga akan mendapatan insentif yang 
juga tinggi. Sebaliknya, agent akan berusaha memenuhi keinginan principal supaya mendapatkan imbalan yang tinggi. Jika tidak ada pengawasan yang baik maka agent akan leluasa memainkan beberapa kondisi sehingga perusahan seolah-olah mencapai target (Watt and Zimmerman, 1986).

Permainan ini dapat terjadi karena principal ataupun inisiatif agency yang curang sehingga akan terjadi berbagai kecurangan seperti akuntansi yang tidak sesuai dengan aturan yang berlaku, contohnya piutang yang sebenarnya tidak bisa tertagih tetapi tidak dihapuskan, kapitalisasi biaya yang tidak wajar atau adanya penjualan yang tidak realistis, selain itu perbankan syariah juga dapat membuat kebijakan yang sangat berbeda dengan transaksi yang berlaku didalam perbankan dilakukan dengan melakukan income smoothing (membagi keuntungan ke periode lain) ini bertujuan supaya setiap tahun perusahaan akan terlihat mendapat keuntungan, yang pada kenyataannya perusahaan sedang mengalami kerugian ataupun terjadi penurunan laba (Elqorni 2009).

\section{Kinerja Perbankan Syariah}

Kinerja ialah cerminan dari hasil yang dicapai perusahaan dalam seluruh kegiatan operasional baik didalam aspek kuangan, aspek pemasaran, aspek penghimpunan dana dan penyaluran dana, aspek teknologi maupun aspek sumber daya manusianya (Jumingan, 2006:239). Kinerja keuangan adalah bentuk pencapaian perusahaan yang dapat didefenisikan dengan hasil yang telah didapat atas aktifitas-aktifitas yang sudah dilakukan. Sehingga didefenisikan juga kinerja keuangan yaitu analisis yang dibuat demi menilai apakah perusahaan tersebut sudah patuh terhadap seluruh aturan yang berlaku, (Fahmi 2012:2). Kinerja dalam penelitian ini akan diukur menggunakan rasio ROA.

Return On Assets (ROA) merupakan rasio untuk mengukur tingkat kemampuan perusahaan memperoleh laba bersih menggunakan tingkat asset tertentu. Hasil rasio yang tinggi akan memperlihatkan efisiensi manajemen aset, yang juga merupakan efisiensi manajemen (Hanafi dan Halim, 2012: 176). Biaya awal yang sudah dikurangi dengan penyusutan digunakan sebagai penilaian aset pada pembukuan perusahaan. Tingkat pengembalian aset yang tinggi tidak selalu memiliki makna bahwa anda bisa membeli aset yang sama saat ini dan mendapatkan tingkat pengembalian yang tinggi. Tingkat pengembalian yang rendah juga tidak menunjukan jika aset tersebut dapat digunakan dengan lebih baik di tempat lain (Brealey, Myers dan Marcus, 2006: 81).

Menurut Haris (2013:1-7), dalam pandangan islam adalah bank adalah Suatu lembaga intermediasi yang mengalirkan dana investasi publik secara optimal (dengan kewajiban zakat dan pelarangan riba) yang bersifat produktif (dengan adanya pelarangan judi), yang tentunya etika dan sistemnya memakai nilai Islam. Bank syariah juga memilki pengertian yaitu sebagai lembaga keuangan/perbankan yang operasional dan produknya dibuat berdasarkan Al-Qur'an dan AlHadits.

\section{Dewan Komisaris}

Dewan komisaris ialah dewan yang bertugas mengawasi baik itu secara umum ataupun khusus sesuai dengan anggaran dasar serta memberi nasihat kepada direksi yang tercantum pada Undang-Undang Nomor 40 tahun 2007 tentang Perseroan Terbatas : Jumlah, komposisi kriteria, rangkap jabatan, hubungan keluarga, dan persyaratan lain bagi anggota dewan komisaris sepenuhnya diatur oleh ketentuan otoritas terkait. Makna dari "ketentuan otoritas terkait" yaitu ketentuan otoritas mengenai bank umum syariah; ketentuan otoritas mengenai uji 
kelayakan/keampuan dan kepatutan (fit and proper test); dan ketentuan otoritas mengenai tenaga kerja asing.

\section{Komite Audit}

Komite audit ialah beberapa orang yang dipilih dan diberikan tugas untuk mengerjakan perkerjaan tertentu atau untuk melakukan beberapa tugas khusus atau sejumlah anggota Dewan Komisaris perusahaan klien yang memiliki tanggungjawab untuk menolong auditor dalam rangka mempertahankan independensinya dari manajemen, (Tugiman,1995). Peraturan Bank Indonesia nomor 11/33/PBI/2009 menyebutkan bahwa komite audit ialah pihak independen yang akan memalkukan penilaian terhadap pelaksanaan audit internal dalam rangka menilai kemaksimalan pengendalian internal termasuk cukup atau tidaknya proses pelaporan keuangan. Anggota Komite Audit minimalnya harus memenuhi beberapa syarat menurut Peraturan Bank Indonesia tersebut.

\section{Dewan Pengawas Syariah (DPS)}

Sunandar (2005) Dewan Pengawas Syariah (DPS) yaitu badan yang memiliki otoritas untuk melakukan supervisi ataupun pengawasan serta mengamati secara dekat aktivitas lembaga keuangan syariah sehingga tidak ada aktivitas lembaga tersebut yang tidak mengikuti aturan atau tidak berprinsip syariah. Didalam peraturan Bank Indonesia nomor 11/33/PBI/2009 dewan pengawas syariah (DPS) memiliki pengertian yaitu dewan yang memiliki tugas memberi nasehat serta saran kepada direksi serta melakukan pengawasan terhadap setiap kegiatan bank agar tidak melenceng dari Prinsip Syariah. Peraturan tentang jumlah anggota dan syarat untuk menjadi anggota DPS sepenuhnya diatur dalam peraturan Bank Indonesia. Pengangkatan Anggota DPS dilakukan melalui RUPS.

Dewan Pengawas Syariah memiliki fungsi ganda dalam perusahaan, fungsi yang pertama adalah sebagai pihak internal yaitu melakukan pengawasan syariah terhadap aktifitas perusahaan. Fungsi yang kedua sebagai pihak eksternal yaitu sebagai sarana atau badan yang berfungsi untuk meningkatkan kepercayaan masyarakat. Alasan utama dibentuknya DPS pada lembaga perbangkan syaraiah adalah untuk memastikan seluruh aktifitas-aktifitas serta prinsip-prinsip yang dilakukan perbankan syariah tidak melenceng dari aturan yang ada. DPS juga menjadi kontrol yang kuat bagi perusahaan. Tugas DPS yang tidak kalah penting yaitu memberikan rekomendasi kepada perusahaan agar seluruh aktifitas operasianal yang dilakukan peusahaan sesuai dengan prinsip syariah yang berlaku, (Fahmi 2014: 40).

\section{PENGEMBANGAN HIPOTESIS}

\section{Pengaruh Dewan Komisaris terhadap Kinerja Perbankan Syariah}

Dewan komisaris memiliki tugas penting yaitu mengawasi dan memberikan rekomendasi kepada dewan direksi perusahaan. Dewan komisaris tidak mempunyai wewenang secara langsung terhadap perusahaan. Fungsi utama DPS adalah melakukan pengawasan terhadap kelengkapan dan kualitas informasi laporan atas kinerja dewan direksi. Dewan komisaris memiliki posisi yang sangat penting dalam menghubungkan kepentingan principal dalam sebuah perusahaan. Peraturan tentang perseroan terbatas tentnag dewan komisaris ada pada UU Nomor 40 tahun 2007 pasal 108 ayat 5, menjelaskan bahwa setiap perusahaan berbentuk perseroan terbatas wajib mempunyai anggota dewan komisaris minimum 2 orang. Dewan komisaris melakukan pengawasan memiliki tujuan supaya pihak manajemen melakukan tugasnya dengan benar (Sutedi 2011: 142). 
Dewan komisaris memiliki tugas yaitu bertanggung jawab penuh untuk melakukan pengawasan, maka semakin besar jumlah anggota dewan komisaris, maka secara otomatis pengawasan yang dilaksanakan akan semakin baik, hal ini diperkuat dengan hasil penelitian Decow, et al. (1996) dan Beasly (1996) serta Sameani (2008) yang menemukan adanya hubungan yang signifikan antara dewan komisaris dengan kinerja. Semakin besar jumlah dewan komisaris yang ada dalam perusahaan tentunya akan memberikan pengawasan serta kontrol yang jauh lebih baik terhadap proses akuntansi dan keuangan sehingga akan memberikan pengaruh positif terhadap kinerja. Arah hubungan dewan komisaris terhadap kinerja ialah positif, (Bukhori, 2012).

H1 : Dewan Komisaris berpengaruh positif signifikan terhadap Kinerja pada Perbankan Syariah di Indonesia Periode 2014 - 2018

\section{Pengaruh Komite Audit terhadap Kinerja Perbankan Syariah}

Komite audit memiliki peran yang sangat penting, ini disebabkan karena pengawasan komite audit dapat berpengaruh terhadap kinerja perusahaan secara umum. Menurut Familia (2010) dan Wicaksono (2014) komite audit mempunyai hubungan positif terhadap profitabilitas perusahaan. Dalam penilitian ini komite audit diukur dengan menggunakan jumlah komite audit. Semakin besar jumlah komite audit yang ada dalam suatu perusahaan maka akan memberikan protection serta control yang lebih baik terhadap proses akuntansi dan keuangan sehingga akan memberikan pengaruh positif terhadap kinerja keuangan perusahaan (Anderson et al., 2004).

Pendapat ini selaras dengan hasil penelitian Gil dan Obradovich (2012), Tetty Sulestiyo Rini (2012) serta Arifiningtiyas Widyaningrum (2014) yang menemukan adanya hubungan positif antara komite audit dengan kinerja keuangan. Disimpulkan yakni pada setiap adanya peningkatan jumlah anggota komite audit maka akan menandakan baiknya kinerja perusahaan. Arah hubungan komite audit juga diperkuat dalam penelitian Kuslinah Riniati (2015) Gil dan Obradovich (2012), yang memperlihatkan Komite Audit berpengaruh terhadap Kinerja perusahaan.

H2: Komite Audit berpengaruh positif signifikan terhadap Kinerja pada Perbankan Syariah di Indonesia Periode $2014-2018$.

\section{Pengaruh Dewan Pengawas Syariah terhadap Kinerja Perbankan Syariah}

Dewan pengawas syariah (DPS) merupakan lembaga independen atau hakim khusus dalam fiqh muamalat, tetapi DPS bisa juga anggota diluar ahli fiqh muamalat. DPS bukan hanya lembaga yang memiliki kewajiban mengawasi aktifitas-aktifitas lembaga keuangan tetapi DPS juga memberikan pengarahan serta meninjau kembali segala aktifitas tersebut agar lembaga keuangan dipercaya sudah menjalankan aturan dan berprinsip syariat islam, (Harahap, 2002: 207). Dewayanto (2010) menyatakan bahwa jumlah dewan pengawas syariah berbanding lurus dengan kinerja perusahaan, bahwa jika jumlah DPS dalam lembaga keuangan semakin banyak, maka pengawasan terhadap manajemen perusahaan akan semakin baik, serta membuat pengelolaan bank syariah akan sesuai sengan prinsip syariah, hal ini juga akan membuat tidak adanya penggunaan dana yang tidak memakai prinsip syariah didalam perusahaan. Dewan pengawas syaraiah memiliki arah hubungan yang positif terhadap kinerja. Berdasarkan pemikiran diatas maka diturunkan hipotesis yaitu:

H3 : Dewan Pengawas Syariah berpengaruh positif signifikan terhadap Kinerja pada Perbankan Syariah di Indonesia Periode 2014 - 2018 


\section{KERANGKA KONSEPTUAL}

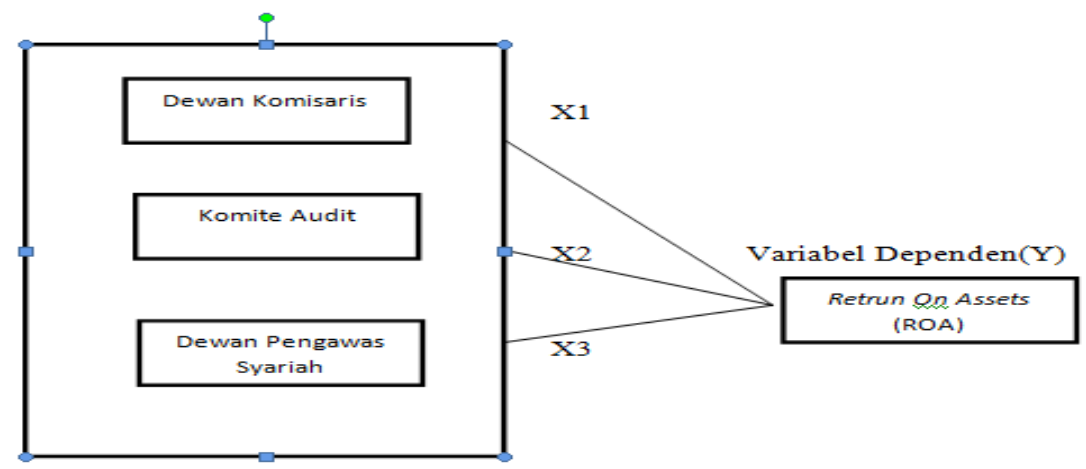

\section{Gambar 1 \\ Kerangka Konseptual}

\section{METODE PENELITIAN}

\section{Jenis Penelitian}

Jenis penelitian yang dipakai pada penelitian ini menggunakan metode deskriptif kuantitatif dengan analisis data statistik, yaitu penelitian yang dilakukan bertujuan mengumpulkan, mengolah, menguji dan menganalisis suatu data yang berupa angka-angka. Data yang didapat dalam penelitian ini yaitu berupa data angka ROA yang didapat dari laporan tahunan mulai dari tahun 2014 sampai tahun 2018. Penelitian ini bertujuan untuk melihat pengaruh Dewan Komisaris, Komite Audit, dan Pengawas Syariah terhadap Kinerja.

Metode kuantitatif ialah metode penelitian yang didasari sifat positivisme, yang kegunaannya untuk meneliti pada populasi atau sampel tertentu, pengumpulan data yang digunakan yaitu instrument penelitian, analisis data bersifat kuantitatif/statistik, dengan tujuan untuk menguji hipotesis yang telah ditetapkan (Sugiyono, 2016: 8).

\section{Populasi Sampel dan Teknik Pengambilan Sampel Populasi}

Menurut Sugiyono (2016: 55), populasi dapat diartikan dengan wilayah yang digeneralisasikan, terdiri dari atas objek yang mempunyai karakteristik tertentu yang ditetapkan oleh peneliti untuk dipelajari dan kemudian diambil kesimpulan. Populasi dalam penelitian ini adalah 12 Bank Umum Syariah (BUS) di Indonesia pada periode 2014-2018.

\section{Sampel}

Sampel ialah bagian kecil dari populasi yang karakteristiknya akan diselidiki dan dianggap mampu mewakili seluruh populasi (jumlahnya sedikit dari pada jumlah populasinya) (Djarwanto dan Subagyo, 2000: 108). Pengambilan sampel dalakukan dengan menggunakan teknik Purposive sampling. Sampel yang digunakan dalam penelitian ini adalah 10 bank umum syariah di Indonesia periode 2014-2018.

\section{Teknik Pengumpulan Data}

Data yang diperoleh dalam penelitian ini dikumpulakn melalui teknik dokumentasi yang didasari oleh literatur yang telah dipublikasikan oleh perusahaan. Data dadapatkan dari laporan tahunan perusahaan (annual report) melalui situs resmi www.idx.co.id selama periode pengamatan, yaitu tahun 2014-2018. 


\section{Variabel enelitian dan Pengukuran}

Variabel penelitian dapat diartikan segala sesuatu yang berbentuk apa saja yang ditetapkan oleh peneliti untuk dipelajari sehingga akan didapatkan informasi mengenai hal tersebut, kemudian dapat ditarik kesimpulanya. Dalam konteks ini sesuatu variabel yang merupakan simbol yang diberi angka atau nilai. Dalam suatu penelitian terkadang melibatkan beberapa variabel, (Sugiyono, 2016: 38). Penelitian ini memiliki variabel yaitu:

1. Variabel Terikat (Dependen Variabel )

Variabel Dependen dalam penelitian ini adalah Kinerja Keuangan yaitu Return On Assets (ROA). ROA diartikan sebagai Rasio untuk mengukur kemampuan perusahaan mandapatkan laba bersih berdasarkan tingkat aset tertentu. Rasio yang tinggi memperlihatkan efisiensi dari manajemen aset, yang berarti efisiensi manajemen (Hanafi dan Halim, 2012: 176). Rasio ini bisa dihitung sebagai berikut :

$$
\frac{\text { Laba Bersih }}{\text { Total Aktiva }}=\cdots \%
$$

2. Variabel Bebas (Independent Variabel )

a) Dewan komisaris

Dewan komisaris memiliki pengerrtian yakni organ perseroan yang memiliki tugas yaitu mengawasi baik secara umum ataupun khusus sesuai dengan anggaran dasar serta memberi nasihat kepada direksi yang terdapat didalam Undang-Undang Nomor 40 tahun 2007 tentang Perseroan Terbatas: Jumlah, komposisi kriteria, rangkap jabatan, hubungan keluarga, dan persyaratan lain bagi anggota dewan komisaris sepenuhnya patuh kepada ketentuan otoritas terkait. Dewan Komisaris diukur dengan cara menghitung jumlah anggota dewan komisaris yang dimiliki perusahaan perbankan.

b) Komite Audit

Komite audit ialah suatu komite yang bekerja secara profesional dan independen yang yang merupakan kaki tangan dewan komisaris dalam rangka membantu melaksanakan tugas dan fungsinya. Peraturan tentang keanggotaan komite audit diatur dalam Surat Edaran dari Direksi PT Bursa Efek Jakarta No. SE-008/BEJ/12-2001 Tanggal 7 Desember 2001, komite audit minimal terdiri dari tiga orang anggota, satu orang diantaranya merupakan komisaris independen yang juga merangkap sebagai ketua komite audit. Dalam penelitiasn ini komite audit akan diukur dengan cara menghitung jumlah anggota komite audit yang dimiliki oleh suatu perusahaan (Utomo dan Chariri 2014).

c) Dewan Pengawas Syariah

Menurut Undang-Undangpasal 20 ayat (2) dalam pelaksanaan fungsinya, Dewan Pengawas Syariah diwajibkan mengikuti fatwa Dewan Syariah Nasional. Dewan Pengawas Syariah dapat diukur dengan menggunakan jumlah anggota Dewan Pengawas Syariah yan ada dalam suatu persahaan perbankan. 


\section{Teknik Analisis Data}

Analisis data penelitian merupakan bagian dari proses uji data setelah selesai tahap pemilihan dan pengumpulan data penelitian. Tahap-tahap dalam melakukan analisis data pada penelitian ini adalah sebagai berikut:

\section{Statistika Deskriptif}

Statistik deskriptif digunakan untuk menjelaskan nilai maksimum, nilai minimum, rata-rata dan standar deviasi dari variabel independen yaitu dewan komisaris, komite audit dan dewan pengawas syariah serta variabel dependen yaitu kinerja perbankan syariah.

\section{Analisis induktif}

a) Model regresi data panel

Data panel ialah penggabungan data silang (cross section) dengan data runtut waktu (time series). Persamaan untuk regresi data panel ini adalah sebagai berikut:

$$
\mathrm{ROA}=\mathrm{a}+\beta_{1} D K+\beta_{2} K A+\beta_{3} D P S+\varepsilon
$$

b) Metode estimasi model regresi panel

Common Effect Model (CEM). Common effect model adalah model yang menggabungkan data time series dan cross section. Model ini memperhatikan dimensi waktu maupun individu sehingga dianggap perilaku data perusahaan sama dalam kurun waktu serta model ini menggunakan pendekatan Ordinary Least Square (OLS) untuk memperkirakan model data panel.

Fixed Effect Model (FEM). Model ini memperkirakan perbedaan individu dapat diakomodasikan dari perbedaan intersepnya. Model ini mengestimasikan data panel menggunakan variabel dummy untuk mengetahui adanya perbedaan intersep. Pendekatan dengan variabel dummy disebut juga least square dummy variables (LSDV).

Random Effect Model (REM). Model ini mengestimasi data panel yang variabel gangguan mungkin saling berhubungan antar waktu dan antar individu. Model ini mengakomodasikan perbedaan intercept melalui error terms masing-masing perusahaan. Model ini memiliki keuntungan yaitu menghilangkan heteroskedastisitas, model ini juga dapat disebut dengan Generalied Least Square (GLS).

3. Pemilihan Model

a. Chowtest atau Likelyhood test

Uji yang digunakan untuk melakukan seleksi antara model fixed effect dan common effect dengan menggunakan Statistik Chi Square, jika probabilitas hasil uji Chi Square tidak lebih besar dari nilai kritisnya, yaitu (0.05) maka H0 ditolak dan Ha diterima.

\section{$\mathrm{H}_{0}$ :Common Effect Model atau Pooled OLS}

$\mathrm{H}_{\mathrm{a}}$ :Fixed Effect Model

\section{b. Haussman test}

Haussman test ialah uji statistik yang memilih apakah model fixed effect atau random effect yang baik digunakan. Jika dalam uji Chow dadapat model yang terbaik digunakan adalah fixed effect, maka kita akan menguji model fixed effect dengan random effect untuk 
menguji model yang baik dianta keduanya. Jika nilai statistik Haussman lebih kecil dari nilai kritisnya (0.05) maka $\mathrm{H}_{\mathrm{a}}$ diterima (model yang tepat adalah fixed effect model) dan sebaliknya. Jika model common effect atau fixed effect yang digunakan, maka langkah selanjutnya yaitu melakukan uji asumsi klasik. tetapi jika model yang digunakan random effect, maka tidak perlu dilakukan uji asumsi klasik

\section{c. Lagrange Multiplie test (LM)}

Lagrange multiplier test adalah uji statistik untuk menyeleksi apakah model random effect atau common effect yang paling tepat digunakan. Jika nilai statistik LM lebih tinggi dari nilai kritisnya (0.05) maka maka Ha diterima (model yang tepat digunakan adalah random effect model) dan sebaliknya. Hipotesis yang diajukan adalah sebagai berikut:

\section{H0 :Common Effect Model \\ Ha :Random Effect Model}

\section{Uji Model}

\section{Koefisien Determinasi $\left(\mathbf{R}^{2}\right)$}

Koefisien Determinasi $\left(\mathrm{R}^{2}\right)$ digunakan untuk melihast sejauh mana kemampuan model dalam menjelaskan variasi variabel dependen. Besarnya koefisien determinasi adalah nol sampai dengan satu. Semakin mendekati nol, semakin kecil pula pengaruh semua variabel independen (X) terhadap nilai variabel dependen (Y). Jika koefisien determinasi mendekati satu, maka sebaliknya. Nilai koefisien determinasi ditunjukan dengan nilai Adjusted $R$ Square.

\section{Uji Simultan (Uji F)}

Uji $\mathrm{F}$ dilakukan untuk mengetahui apakah variabel indepen dalam penelitian secara simultan mempengaruhi variabel dependen. $F_{\text {hitung }}$ yang lebih besar daripada $F_{\text {tabel, }}$ menunjukkan model regresi linear berganda yang digunakan dapat dilanjutkan atau diterima, dengan tingkat kepercayaan untuk pengujian hipotesis $(\alpha)=0,05$.

\section{Uji t-Test ( Uji Hipotesis)}

Langkah berikutnya ialah melakukan pengujian untuk mengetahui kemampuan tiap-tiap variabel independen dalam menjelaskan perilaku variabel dependen. Pengujian dilakukan dengan menggunakan tingkat signifikansi 0,05.

\section{HASIL PENELITIAN DAN PEMBAHASAN}

\section{A. Statistik Deskriptif}

\begin{tabular}{|c|c|c|c|}
\hline \multicolumn{4}{|c|}{ Tabel 1 } \\
\hline \multicolumn{4}{|c|}{ Statistik Deskriptif } \\
\hline & Y & PS & AQ \\
\hline Mean & -0.003070 & 3.600000 & 3.720000 \\
\hline Median & 0.003600 & 3.000000 & 3.000000 \\
\hline Maximum & 0.022800 & 6.000000 & 7.000000 \\
\hline Minimum & -0.218900 & 2.000000 & 2.000000 \\
\hline Std. Dev. & 0.036546 & 0.925820 & 1.325419 \\
\hline
\end{tabular}

Sumber : Data Olahan Eviews Tahun 2019 
Data penelitian yang menjadi variabel dependen (Y) dalam penelitian ini yakni Kinerja Perbankan Syariah, sedangkan yang menjadi variabel independen (X1) yaitu Dewan Komisaris (X2) yaitu Komite Audit (X3) yaitu Dewan Pengawas Syariah. Kinerja Perbankan Syariah mempunyai rata-rata -0,0031 dengan standar deviasi 0.0365 Kinerja Perbankan Syariah tertinggi adalah 0.0228 dan kinerja perbankan syariah terendah -0.2189 . Variabel Dewan Komisaris memiliki rata-rata 3.6000, dengan standar deviasi 0.9258, Dewan Komisaris tertinggi adalah 6.0000dan terendah 2.0000. Variabel Komite Audit menunjukkan rata-rata 3.7200 dengan standar deviasi 1.3254, Komite Audit tertinggi adalah 7.0000 dan terendah 2.0000.Variabel Dewan Pengawas Syariah memperlihatkan rata-rata 2.2600 dengan standar deviasi 0. 4431, Dewan Pengawas Syariah tertinggi adalah 3.0000 dan terendah 2.0000 .

\section{B. Analisis Induktif}

1. Analisis Model Regresi Panel

a) Chow Test atau Likelyhood Test

Tabel 2

Hasil Uji Chow Test atau Likelyhood Test

\begin{tabular}{|l|r|r|r|}
\hline Effects Test & Statistic & d.f. & Prob. \\
\hline Cross-section F & 1.912826 & $(9,37)$ & 0.0805 \\
\hline Cross-section Chi-square & 19.102382 & 9 & 0.0243 \\
\hline
\end{tabular}

Berdasarkan hasil uji Chow test dengan menggunakan eviews8 diperoleh probabilitas sebesar 0.0243. Nilai probabilitasnya kecil dari level signifikan $(a=0.05)$ maka Ha untuk kedua model ini diterima dan $\mathrm{H} 0$ ditolak, sehingga estimasi yang lebih baik digunakan dalam model ini adalah Fixed Effect Model (FEM) dengan demikian perlu dilanjutkan ke uji Haussman test.

\section{b) Haussman test}

Tabel 3

Hasil Uji Haussman Test

\begin{tabular}{|l|r|r|c|}
\hline Test Summary & Chi-Sq. Statistic & Chi-Sq. d.f. & Prob. \\
\hline Cross-section random & 0.437265 & 3 & 0.9324 \\
\hline
\end{tabular}

Berdasarkan uji Haussman test menggunakan eviews8, diperoleh probabilitas sebesar 0.9324 . Nilai probabilitasnnya lebih besar dari level signifikan $(a=0.05)$, dengan demikian H0 untuk model ini diterima dan Ha ditolak. Sehingga estimasi yang lebih baik digunakan dalam model ini adalah Random Effect Model (REM).

\section{Uji Model}

Tabel 4

Hasil Uji Random Effect Model

\begin{tabular}{|c|r|r|r|r|}
\hline Variable & Coefficient & Std. Error & t-Statistic & Prob. \\
\hline & & & & \\
\hline C & 0.003855 & 0.084834 & 0.045436 & 0.9640 \\
\hline DK & 0.006145 & 0.009438 & 0.651044 & 0.5190 \\
\hline KA & -0.007322 & 0.010306 & -0.710461 & 0.4819 \\
\hline
\end{tabular}




\begin{tabular}{|l|r|c|r|r|}
\multicolumn{1}{|c|}{ DPS } & -0.000800 & 0.030297 & -0.026405 & 0.9791 \\
\hline \hline & \multicolumn{2}{|c|}{ Weighted Statistics } & & \\
\hline R-squared & 0.377275 & Mean dependent var & -0.003070 \\
\hline Adjusted R-squared & 0.175310 & S.D. dependent var & 0.036546 \\
\hline S.E. of regression & 0.033189 & \multicolumn{2}{|c|}{ Akaike info criterion } & -3.754 .332 \\
\hline F-statistic & 1.868 .022 & Durbin-Watson stat & 2.297 .109 \\
\hline Prob(F-statistic) & 0.072287 & & & \\
\hline
\end{tabular}

\section{Uji Koefisien Determinasi $\left(R^{2}\right)$}

Nilai adjusted $R^{2}$ yang diperoleh sebesar 0.801 . Hal ini mengindikasikan bahwa kontribusi variabel independen terhadap variabel dependen sebesar 17,5\% dan sebesar 82,5\% ditentukan oleh variabel lain yang tidak dianalisis dalam penelitian ini..

\section{Uji F (Simultan)}

(F-statistic) yang diperoleh sebesar diperoleh sebesar 0.072287 lebih kecil dari sig (0.1). Hal ini menandakan bahwa model panel diterima, sehingga dapat dikatakan variabel independen berpengaruh secara bersama-sama terhadap variabel dependen.

\section{Uji Hipotesis (t-Test)}

Hipotesis pertama dalam penelitian ini ialah dewan komisaris (DK) yang memiliki pengaruh positifsignifikan terhadap kinerja perbankkan syariah. Tabel 4 di atas dapat kita ketahui bahwa dewan komisaris memiliki nilai koefisien bernilai positif sebesar 0.0061 , nilai t sebesar 0,6510 , tabel $2,4469(0,6510<2,4469)$ dengan nilai signifikansi sebesar 0,5190 , hal ini menunjukkan bahwa penelitian ini tidak dapat membuktikan dewan komisaris berpengaruh positif signifikan terhadap kinerja perbankkan syariah. Jadi dapat disimpulkan bahwa hipotesis 1 ditolak.

Hipotesis kedua dalam penelitian ini adalah komite audit berpengaruh positif signifikan terhadap kinerja perbankkan syariah. Tabel 4 di atas dapat kita ketahui bahwa komite audit memiliki nilai koefisien bernilai negatif sebesar $-0,0073$ nilai ti sebesar $-0,7105, t_{\text {tabel }} 2,4469$ ($0,7105<2,4469$ ) dengan nilai signifikansi sebesar 0,4819 , hal ini menunjukkan bahwa penelitian ini tidak mampu membuktikan komite audit berpengaruh positif signifikan terhadap kinerja perbankan syariah. sehingga dapat disimpulkan bahwa hipotesis 2 ditolak.

Hipotesis ketiga dalam penelitian ini adalah dewan pengawas syariah berpengaruh positif signifikan terhadap kinerja perbankkan syariah. Tabel 4 di atas dapat kita ketahu bahwa dewan pengawas syariah memiliki nilai koefisien bernilai negatif sebesar -0,0008 nilai t sebesar -0,0264, $\mathrm{t}_{\text {tabel }} 2,4469(-0,0264<2,4469)$ dengan nilai signifikansi sebesar 0,9791, hasil ini memperlihatkan bahwa penelitian ini tidak dapat membuktikan dewan pengawas syariah berpengaruh positif signifikan terhadap kinerja perbankan syariah. Jadi dapat disimpulkan bahwa hipotesis 3 ditolak.

\section{PEMBAHASAN}

Penelitian ini menunjukkan bahwa variabel dewan komisaris, komite audit dan dewan pengawas syariah berpengaruh signifikan positif terhadap kinerja perbankan syariah. Nilai total adalah $17.5 \%$, sedangkan menurut Guilford (1956) hasil 0-20\% menunjukkan bahwa pengaruh semua variabel sangat lemah. 


\section{Pengaruh Dewan Komisaris terhadap Kinerja Perbankan Syariah}

Berdasarkan hasil analisis statistik dalam penelitian ini ditemukan bahwa hipotesis pertama dalam penelitian ini ditolak. Penelitian ini membuktikan bahwa dewan komisaris tidak berpengaruh terhadap kinerja perbankan syariah, dapat dilihat dari nilai koefisien yang meskipun bernilai positif sebesar 0,0061 akan tetapi nilai signifikansinya sebesar 0,5190. Hasil ini menunjukan semakin banyak jumlah dewan komisaris maka akan semakin rendah kinerja perusahaan. maknanya besar atau kecil jumlah dewan komisaris tidak mempengaruhi kinerja pada perusahaan.

Hasil ini terjadi disebabkan karena pada sektor keuangan terdapat banyak pihak luar perusahaan yang mengawasi kinerja perusahaan, khususnya pada sektor keuangan dan regulasi yang ditetapkan perusahaan. Hasil penelitian ini juga ditolak diduga karena masih ada bank umum syariah dengan jumlah dewan komisaris dibawah ketentuan undang-undang yang berlaku. Pasal 25 PBI No. 11/3/PBI 2009 adalah pasal yang mengatur tentang Bank Umum Syariah dan Anggaran Dasar Perusahaan, yang menetapkan bahwa jumlah angota Dewan Komisaris paling kurang 3 (tiga) orang dan paling banyak sama dengan jumlah anggota Direksi. Kurangnya jumlah dewan komisaris tentu akan membuat tidak maksimalnya pengawasan terhadap aktivitas perbankan.

Pentingnya dewan komisaris dalam peningkatan kinerja perbankan syariah, karena dengan adanya pengawasan terhadap kegiatan atau aktivitas yang dilakukan perbankan akan menyebabkan aktivitas-aktivitas yang dilakukan akan sesuai dengan tujuan dari parbankan sehingga akan membuat kinerja semakin meningkat

\section{Pengaruh Komite Audit terhadap Kinerja Perbankan Syariah}

Berdasarkan hasil analisis statistik dalam penelitian ditemukan bahwa hipotesis kedua dalam penelitian ini ditolak. Penelitian ini membuktikan bahwa komite audit tidak berpengaruh terhadap kinerja perbankan syariah, dapat dilihat dari nilai koefisien yang bernilai negatif sebesar $-0,0073$, dan nilai signifikansinya sebesar 0,4819 . Hasil ini dapat disimpulkan bahwa tidak terdapat pengaruh dewan komisaris terhadap kinerja perbankan syariah. Artinya jumlah komite audit yang besar tidak menjamin keefektifan dalam pengawasan pada bank umum syariah. Ditunjukan melalui uji t dimana thitung < ttabel, $(-0,7104<2,4469)$, maka H2 ditolak artinya jumlah komite audit tidak berpengaruh secara signifikan terhadap kinerja perbankan syariah untuk tahun 2014-2018.

Penelitian ini memiliki hasil yang sama dengan penelitian yang dilakukan oleh Adestian (2015: 10), namun tidak sejalan dengan Anderson et al (2004), Familia (2010) dan Wicaksono (2014), yang menemukan komite audit memiliki hubungan positif terhadap profitabilitas perusahaan. Dengan adanya komite audit didalam perusahaan, diharapkan akan mampu menciptakan laporan keuangan yang relevan sehingga dapat digunakan sebagai evaluasi bagi manajemen.

\section{Pengaruh Dewan Pengawas Syariah terhadap Kinerja Perbankan Syariah.}

Berdasarkan hasil analisis statistik dalam penelitian ini menemukan bahwa hipotesis ketiga dalam penelitian ini ditolak. Penelitian ini memberi bukti bahwa dewan pengawas syariah tidak memiliki pengaruh terhadap kinerja perbankan syariah, terlihat dari nilai koefisien yang bernilai negatif sebesar $-0,0008$, dan nilai signifikansi sebesar 0,9791 . Hasil ini dapat disimpulkan bahwa tidak ada pengaruh dewan komisaris terhadap kinerja perbankan syariah. Artinya jumlah dewan pengawas syariah yang banyak mengakibatkan kurang efektifnya 
pengawasan yang dilakukan pada bank umum syariah, hal ini sebabkan karena jika semakin besar jumlah dewan pengawas syariah maka akan memungkinkan terdapat perdebatan yang tidak perlu, serta akan ada kemungkinan terjadi penundaan dalam proses pembuatan keputusan.

Penelitian ini sejalan dengan penelitian yang dilakukan oleh Wiwid (2018), namun tidak sejalan dengan penelitian Chtourou, dkk (2001) dalam Dewayanto (2010), yang menyatakan bahwa jumlah dewan pengawas syariah yang semakin besar maka mekanisme pengawasan manajemen perusahaan akan semakin baik.

\section{KESIMPULAN DAN SARAN \\ Kesimpulan}

1. Berdasarkan hasil pengujian dapat diketahui bahwa variabel dewan komisaris berpengaruh negatif siginifikan terhadap Kinerja Perbankan Syariah, oleh karena itu hipotesis pertama yang menyatakan bahwa "Dewan Komisaris berpengaruh positif terhadap Kinerja Perbankan Syariah" ditolak.

2. Berdasarkan hasil pengujian dapat diketahui bahwa variabel Komite Audit berpengaruh negatif signifikan terhadap Kinerja Perbankan Syariah, oleh karena itu hipotesis kedua yang menyatakan bahwa "Komite Audit berpengaruh positif terhadap Kinerja Perbankan Syariah" ditolak.

3. Berdasarkan hasil pengujian dapat diketahui bahwa variabel Dewan Pengawas Syariah berpengaruh negatif signifikan terhadap Kinerja Perbankan Syariah, oleh karena itu hipotesis ketiga yang menyatakan bahwa "Dewan Pengawas Syariah berpengaruh positif terhadap Kinerja Perbankan Syariah" ditolak.

\section{Saran}

Berdasarkan kesimpulan dan keterbatasan penelitian yang telah diuraikan sebelumnya, maka saran yang dapat peneliti berikan, yaitu;

1. Perusahaan harus memastikan dewan komisaris dan komite audit mimiliki anggota sesuai dengan ketentuan minimum dari undang-undang yang berlaku agar terlaksananya pengawasan yang maksimal.

2. perusahaan harus memastikan jumlah dewan pengawas syariah tidak hanya untuk memenuhi ketentuan hukum saja tetapi juga melaksananakan tugas secara maksimal.

3. Penilaian disarankan untuk melihat variabel lain, karena variabel yang mempengaruhi kinerja perbankan syariah tidak terbatas pada ukuran Dewan Pengawas Syariah, ukuran Dewan Komisaris, dan Komite audit, namun perlu ditambahkan variabel-variabel lainnya.

\section{DAFTAR PUSTAKA}

Adestian, Y. 2015. Pengaruh Dewan Komisaris, Dewan Direksi Dewan Komisaris Independen, Komite Audit dan Ukuran Perusahaan pada Kinerja Perusahaan Perbankan. Skripsi. UDINUS. Semarang.

Ahmad E. (2009). Mengenal Teori Keagenan (All Management Insight), Elqron wordpress, diakses 26 Februari 2009.

Alijoyo A, Zaini S. 2004. Komisaris Independen: Pengaruh Praktik GCG di Perusahaan. Jakarta. PT indeks Kelompok Gramedia.

Anderson, Ronald C. et al. (2004). Board Characteristics, Accounting Report Integrity, And The Cost Of Debt. Journal Of Accounting And Economics, 37(3), 315-342. 
Anthony, R.N. dan V. Govindarajan. (1995). Management Control System. Eight Edition International Student Edition. Richard D. Irwin Inc. U.S.A.

Brealey, Myers, Marcus. (2006). Dasar-Dasar Manajemen Keuangan Perusahaan. Jakarta. Erlangga.

Bukhori, I dan Raharja. (2012). Pengaruh God Corporate Governance Dan Ukuran Perusahaan Terhadap Kinerja Keungan Perusahaan. Diponegoro Journal of Accounting. pp. 1-12.

Bungin, B. (2013). Metodologi Penelitian Sosial dan Ekonomi Jakarta: PT Fajar.

Chtourou, S. M., J. Bedard., \& L. Courteau. (2001). Corporate Governance and Earnings Management. http:/www.ssrn.com. 1-38.

Dechow, P. M., et al., (1996). Causes and consequences of earning manipulation: An analysis of firm subject to enforcement actions by SEC. Contemporary Accounting Research, 13(1), $1-33$.

Putri, D., M. 2011. Pengaruh Karakteristik Komite Audit Terhadap Manajemen Laba (Studi Empiris pada Perusahaan Manufaktur yang Terdaftar di Bursa Efek Indonesia Periode Tahun 2007-2009). Skripsi. Universitas Diponegoro. Semarang.

Dewayanto, T. (2010). Pengaruh Mekanisme GCG terhadap Kinerja Perbankan Nasional. Diponegoro Journal of Accounting, 5(2), 104-123.

Djarwanto dan Subagyo, P. (2000). Statistik Induktif. Yogyakarta: BPFE Yogyakarta.

Donnelly, James H., Gibson, James L., \& Ivancevich, John. (1994). Fundamental of Management. Texas. Business Publication.

Fahmi. (2014). Pengantar Perbankan Teori dan Aplikasi. Bandung: Alfabeta

Familia, D. 2010. Pengaruh Komite Audit Terhadap Profitabilitas PT. Mulia Industrindo Tbk. . http://library.gunadarma.ac.id/repository/view/642.

Febriani. (2003). Analisis \& Perancangan Sistem Informasi Depok. Universitas Gunadarma.

Gill, A dan Obradovich, J. (2012). The Impact of Corporate Governance and Financial Leverage on the Value of American Firms. International Research Journal of Finance and Economics, 91, 1450-2887.

Hanafi M., M, dan Abdul H. (2012). Analisis Laporan Keuangan, Edisi Keempat. Yogyakarta: UPP STIM YKPN.

Harahap. S. (2002). Analisis Kritis atas Laporan Keuangan. Jakarta: PT. Raja Grafindo Persada.

Haris, H. (2013). Buku Daras Manajemen Dana Bank Syariah. Sleman: Asnalitera.

Hiro, T. 1995. Sekilas: Komite Audit, PT. Eresco, Bandung.

Hisamuddin, N dan Tirta, M.,Y (2012). Pengaruh Good Corporate Governance Terhadap Kinerja Keuangan Bank Umum Syariah Pada Tahun 2008-2010. Jurnal Akuntansi Universitas Jember.

Jumingan. (2006). Analisis Laporan Keuangan, Cetakan Pertama. Jakarta: Bumi Aksara.

Jensen, M C, dan William M. (1976). Theory Of The Firm, Managerial Behavior, Agency Cost, and Ownership Structure. Jurnal of Financial Economic, 3 (4), 305-360

Rahmawati H. (2013). Pengaruh Good Corporate Governance (GCG) Terhadap Manajemen Laba Pada Perusahaan Perbankan. Accounting Analysis Journal AAJ 2 (1)

Ramdiani N., N dan Yadnyana, I., K. 2013. Pengaruh Penerapan Corporate Governance dan Kinerja Keuangan Pada Harga Saham Perbankan yang Terdaftar di Bursa Efek Indonesia Tahun 2009-2011. Skripsi. Bali Fakultas Ekonomi Universitas Udayana. (Online), (http://portalgaruda.org), diakses 29 Maret 2014). 
Riniati,Kuslinah. 2015.Pengaruh Komisaris Independen dan Komite Audit Terhadap Kinerja Perusahaan (Perusahaan yang Terdaftar di BEI 2011-2013). Skripsi. Fakultas Ekonomi Universitas Negeri Yogyakarta.

Rustam, B.R. (2013). Manajemen Resiko Perbankan syariah. Jakarta Selatan: Salemba Empat.

Sugiyono. (2016). Metodologi Penelitian Bisnis. Bandung: Alfabeta.

Sugiono. (2017). Metodologi Penelitian Bisnis. Bandung: Alfabeta.

Sutedi A. (2011). Good Corporate Governance. Jakarta: Sinar Grafika.

Stolovitch, H., D and Keeps, E., J. (1992). Handbook of Human Performance Technology A Comprehensive Guide for Analysis and Solving Performance Problem in Organizations. San Francisco : Jersey-Bass Publisher.

Republik Indonesia. 1945. Undang-Undang Dasar Negara Republik Indonesia 1945 Tentang Penjelasan Umum. Jakarta: Pemerintah Indonesia.

Republik Indonesia. 2007. Undang-Undang Dasar Negara Republik No. 40 Tahun 2007 Pasal 74 Ayat 1 Tentang Perseroan Terbatas. Jakarta: Pemerintah Indonesia.

Utomo, Y., \& Chariri, A. (2014). Determinan Pengungkapan Risiko pada Perusahaan Nonkeuangan di Indonesia. Jurnal Universitas Diponegoro, 3(23), 1-14.

Wicaksono. 2014. Pengaruh Good Corporate Governance Terhadap Profitabilitas Perusahaan (Studi Empiris pada Perusahaan Peserta Corporate Governance Perception Index (CGPI) Tahun 2012). Skripsi. Fakultas Ekonomi dan Bisnis Universitas Diponegoro.

Widyastutik, W., Eka. 2018. Pengaruh Good Corporate Governance terhadap Kinerja Keuangan Bank Umum Syariah. Skripsi. Fakultas Ekonomi IAIN Tulungagung.

Watts, R., L.dan Jerold L. Z. (1986). Positive Accounting Theory. USA: Prentice-Hall.

Wibowo (2009). Manajemen Kinerja. Jakarta: PT. Raja Grafindo Persada. 